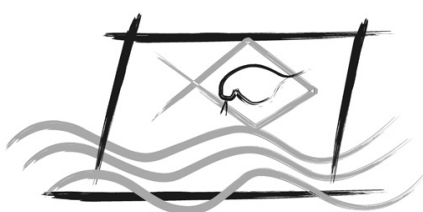

ECOTOX - BRASIL

\title{
Influences of soil pH on cadmium toxicity to eight plant species
}

\author{
De Oliveira, V.H. ${ }^{1 *}$; Melo, L.C.A. ${ }^{2}$; Abreu, C.A. ${ }^{3}$; Coscione, A.R. ${ }^{3}$ \\ ${ }^{1}$ School of Agriculture, Policy and Development, University of Reading. Whiteknights, PO Box 237, Reading, RG6 6AR - UK. \\ ${ }^{2}$ Federal University of Lavras - Department of Soil Science, 37200-000 - Lavras, MG - Brazil. \\ ${ }^{3}$ Center of Soils and Environmental Resources, Agronomic Institute (IAC), Av. Barão de Itapura, 1481 - 13020-902 - Campinas, \\ SP - Brazil.
}

(Received June 02, 2016; Accept September 01, 2016)

\begin{abstract}
Soil pollution by heavy metals affects soil quality worldwide. Cadmium $(\mathrm{Cd})$ is of special concern because it might transfer from soil to plants, especially under acidic conditions, causing toxicity. This work aimed to evaluate the $\mathrm{LC}_{50}$ (lethal concentration to $50 \%$ of studied population), NOEC (no observed effects concentration) and LOEC (lowest observed effects concentration), by measuring the germination and growth of eight plant species (Beta vulgaris, Daucus carota, Lactuca sativa, Phaseolus vulgaris; Avena strigosa, Oryza sativa, Triticum aestivum and Zea mays) in soil under increasing Cd concentrations ( $0,10,40$, 80,160 , and $320 \mathrm{mg} \mathrm{kg}^{-1}$ ) and two levels of acidity. Increasing the soil $\mathrm{pH}$ (from 4.1 to 6.4) by liming alleviated Cd toxicity and had a positive impact on seedling growth of all plant species studied. Germination was a less responsive endpoint and only the most sensitive species ( L. sativa, B. and D. carota) were affected under the most acidic condition. These results were confirmed by the lower values found for $\mathrm{LOEC}$ and $\mathrm{LC}_{50}$ in these species regardless of the soil $\mathrm{pH}$. Sensitive species are thus recommended as indicators of soil contamination in ecotoxicological studies, in which dicotyledonous species (e. g. L. sativa and $B$. vulgaris) are more suitable for risk assessments in Cd-contaminated soils at low concentrations, whilst monocotyledons (e. g. Z. mays) are more adequate for higher Cd concentrations $\left(\geq 80 \mathrm{mg} \mathrm{kg}^{-1}\right)$. Increasing soil $\mathrm{pH}$ by liming was demonstrated to be an efficient method in alleviating $\mathrm{Cd}$ toxicity in seedling growth.
\end{abstract}

Keywords: germination; metal availability; phytotoxicity; seedling growth.

\section{INTRODUCTION}

Cadmium $(\mathrm{Cd})$ is ranked seventh on the list published by the Agency for Toxic Substances and Disease Registry (ATSDR, 2015) of potentially toxic elements that are considered hazardous to the environment. Cadmium is highly toxic to humans and other living organisms even at low concentrations (Smolders \& Mertens, 2013), and it is greatly mobile in soils, leaching into groundwater and contaminating aquifers (Lei et al., 2010). One of the main routes by which humans are exposed to $\mathrm{Cd}$ is the ingestion of plants grown in areas with high contents of this metal (ATSDR, 2008).

An efficient way to assess a contaminant risk in soil is by toxicity tests, which can provide a link between chemical monitoring (analysis) and empirical confirmation of toxic effects caused to biota by the studied element in the environment. Sensitive plant species can be useful bioindicators in ecotoxicity assessment of soils because they can respond quickly to toxic effects of pollutants in terrestrial ecosystems (Gorsuch et al., 1991). Thus, plant bioassays are considered useful and versatile tools not only for identifying pollutant effects in soils, but also for verifying the success of remediation processes for contaminated soils (Loureiro et al., 2006). The endpoints assessed are usually seed germination and seedling growth (Munzuroglu \& Geckil, 2002; Zayneb et al., 2015). Nevertheless, most studies have been based on soil solutions and there is still a need to carry out such assays directly in contaminated soils, to provide results closer to what is observed under field conditions (Guo et al., 2010).

The impacts of soil contamination by metals on the environment are related not only to their total contents or 
chemical forms but also and essentially to their bioavailability (Zhou et al., 2007), especially for $\mathrm{Cd}$, which is affected primarily by soil $\mathrm{pH}$ (Alloway, 2013; Selim \& Iskandar, 1999). Differences in Cd bioavailability due to soil $\mathrm{pH}$ are, therefore, of great importance in ecotoxicological studies, because acidic soils pose a higher risk than other soils.

Therefore, the present work aimed to evaluate the seed germination and initial seedling growth of eight plant species (four monocotyledons and four dicotyledons) in soils with increasing $\mathrm{Cd}$ concentrations at two $\mathrm{pH}$ levels (4.1 and 6.4), as well as to determine ecotoxicity indexes to identify and recommend potentially sensitive species suitable for ecotoxicological risk assessment of $\mathrm{Cd}$ in soils.

\section{MATERIALS AND METHODS}

Plant bioassays were carried out in the laboratory (Agronomic Institute - IAC, Campinas - SP, Brazil) according to Pereira et al. (2009), which is similar to the soil plate bioassay (SPB) regarded as an effective method in determining ecotoxicological risks (Boluda et al., 2011). Eight plant species were selected as being sensitive to heavy metal toxicity, based on the previously mentioned lists of the OECD (2006) and the USEPA (1996). The selected species belong to two distinct groups: - dicotyledons [Lactuca sativa L. (lettuce), Daucus carota L. (carrot), Beta vulgaris L. (beet), and Phaseolus vulgaris L. (common bean)] and monocotyledons [Zea mays L. (maize), Triticum aestivum L. (wheat), Oryza sativa L. (rice), and Avena strigosa Schreb (oat)].

A sample of a non-contaminated Entisol $(0-20 \mathrm{~cm})$ was collected from a natural reserve area. The soil material was air dried, sieved $(<4 \mathrm{~mm})$, and homogenized, and a subsample was taken and sieved $(<2 \mathrm{~mm})$ for characterization. Physical fractionation was performed by the pipette method (Camargo et al., 2009). The soil $\mathrm{pH}$ was determined in a $0.01 \mathrm{M} \mathrm{CaCl}_{2}$ solution at a soil:solution ratio of 1:2.5 (v/v). Chemical characterization was performed according to Raij et al. (2001): $\mathrm{P}, \mathrm{Ca}, \mathrm{Mg}$, and $\mathrm{K}$ contents were determined by ion-exchange resin extraction; organic matter (O.M.) content was determined colorimetrically, using sulfuric acid and potassium dichromate according to Walkley \& Black (1934) with modifications by Frattini \& Kalckmann (1976); Cd, Cu, Fe, Mn, and Zn contents were determined by the DTPA method, at a pH of 7.3 (Abreu et al., 1997), using inductively coupled plasma with optical emission spectrometry (ICP-OES) [Varian, model Vista MPX]; and the soil acidity $(\mathrm{H}+\mathrm{Al})$ was determined by the SMP buffer solution method. The physical and chemical attributes of the soil used are given in Table 1.

The soil was then incubated in appropriate plastic bags with and without dolomitic lime. The amount of lime applied was aimed at raising the base saturation to $70 \%$, and soil moisture content was maintained at $70 \%$ of the maximum soil water holding capacity and replenished weekly by weighing. After 30 days of incubation, the soil $\mathrm{pH}$ levels were 4.1 and 6.4 without and with lime, respectively. Samples of $120 \mathrm{~g}$ of soil were placed in pots and received Cd solutions (prepared with
Table 1 - Physicochemical properties of the test soil used in the study.

\begin{tabular}{lcc}
\hline Property & Unit & Mean $\pm \mathrm{SD}$ \\
\hline Clay & $\mathrm{g} \mathrm{kg}^{-1}$ & $49 \pm 0.82$ \\
Silt & $\mathrm{g} \mathrm{kg}^{-1}$ & $25 \pm 2.83$ \\
Sand & $\mathrm{g} \mathrm{kg}^{-1}$ & $926 \pm 2.16$ \\
$\mathrm{pH}$ & - & $4.1 \pm 0.05$ \\
Org. Matter & $\mathrm{g} \mathrm{kg}^{-1}$ & $11 \pm 0.94$ \\
$\mathrm{P}$ & $\mathrm{mg} \mathrm{kg}^{-1}$ & $3 \pm 0.47$ \\
$\mathrm{~K}$ & $\mathrm{mmol}_{\mathrm{c}} \mathrm{kg}^{-1}$ & $1.4 \pm 0.24$ \\
$\mathrm{Ca}$ & $\mathrm{mmol}_{\mathrm{c}} \mathrm{kg}^{-1}$ & $7 \pm 0.94$ \\
$\mathrm{Mg}$ & $\mathrm{mmol}_{\mathrm{c}} \mathrm{kg}^{-1}$ & $<1 \pm 0.0$ \\
$\mathrm{H}+\mathrm{Al}$ & $\mathrm{mmol}_{\mathrm{c}} \mathrm{kg}^{-1}$ & $13 \pm 4.55$ \\
$\mathrm{CEC}$ & $\mathrm{mmol}_{\mathrm{c}} \mathrm{kg}^{-1}$ & $31.4 \pm 3.48$ \\
$\mathrm{Cd}$ & $\mathrm{mg} \mathrm{kg}^{-1}$ & $<0.01 \pm 0.0$ \\
$\mathrm{Fe}$ & $\mathrm{mg} \mathrm{kg}^{-1}$ & $26 \pm 4.09$ \\
$\mathrm{Mn}$ & $\mathrm{mg} \mathrm{kg}^{-1}$ & $1.2 \pm 0.05$ \\
$\mathrm{Zn}$ & $\mathrm{mg} \mathrm{kg}^{-1}$ & $0.7 \pm 0.05$ \\
$\mathrm{Cu}$ & $\mathrm{mg} \mathrm{kg}^{-1}$ & $0.2 \pm 0.08$ \\
\hline
\end{tabular}

$\mathrm{CdCl}_{2}, 99 \%$ purity) to reach the following final concentrations, in $\mathrm{mg} \mathrm{kg}^{-1}: 10,40,80,160$, and 320 , plus a control treatment (without $\mathrm{Cd}$ addition). Concentration range was based on a past study (An, 2004). Treatments were then left to stand for 24 hours before ten seeds of each species were sown per pot. Cadmium homogenous distribution was assumed due to its high solubility in water and the low contents of clay and organic matter, as described by An (2004). The experiment was carried out according to a completely randomized design with three replicates. The temperature was held constant at 23 ${ }^{\circ} \mathrm{C}$, light was supplied continuously, and the moisture content was maintained at $60 \%$ of the soil water holding capacity and replenished daily by weighing.

Ten days after sewing, three endpoints were assessed: germination and shoot and root growth. Seed germination was evaluated as described by An (2004). A seed was considered as germinated when shoots were evident above the soil surface. Germination rates were calculated by the mean of four treatments $\left(0,10,40\right.$ and $\left.80 \mathrm{mg} \mathrm{kg}^{-1}\right)$, considering total germination (10 seeds) as the reference value (100\%). Germination found in the highest doses of Cd (160 and $320 \mathrm{mg}$ $\mathrm{kg}^{-1}$ ) was not included due to high mortality. Plants were then carefully removed from the soil and washed with deionized water. The lengths of the seedlings' shoots and roots were measured with a digital caliper rule.

The Lethal Concentration $\left(\mathrm{LC}_{50}\right.$ - concentration capable of causing death -or no germination - to $50 \%$ of the population exposed) was calculated according to the Trimmed SpearmanKarber method (Hamilton et al., 1977). In addition, NOEC (No Observed Effects Concentration) and LOEC (Lowest Observed Effects Concentration) values were calculated for all parameters using Dunnett's test, at $p<0.05$ (An et al., 2004; Walker et al., 2001). The germination data were transformed 
by the equation $(x+2)^{2}$, with $\mathrm{x}$ as the observed value. This transformation was applied to obtain a normal distribution of the data and allow statistical analysis. The effect of soil $\mathrm{pH}$ was assessed by Student's t-test $(p<0.05)$ for each species and parameter evaluated (germination and root and shoot elongation), except when most plants died at the highest concentrations. The $\mathrm{LC}_{50}$ was calculated using the Spearman program (USEPA, 1999), and other results were evaluated by using the R software (R Development Core Team, 2008).

\section{RESULTS AND DISCUSSION}

Germination and shoot and root growth varied according to the species and the soil $\mathrm{pH}$ (Table 2). L. sativa, B. vulgaris, and $D$. carota were the most responsive species to $\mathrm{pH}$ variation for all endpoints assessed, whereas $P$. vulgaris and the monocotyledon species showed a response to $\mathrm{pH}$ variation only for seedling growth. At the higher soil $\mathrm{pH}$ (6.4), shoot and root growth were greater than at the lower $\mathrm{pH}(4.1)$ for all species evaluated. The exception was $T$. aestivum, for which root growth was unaffected, and also A. strigosa, which exhibited an increase only in root growth, suggesting that this species has less $\mathrm{Cd}$ translocation to shoots, making root growth a more responsive endpoint to $\mathrm{Cd}$ toxicity. These results show that the liming technique greatly attenuated $\mathrm{Cd}$ toxic effects in all species studied.
Higher phytotoxicity in acidic soils ( $\mathrm{pH}$ between 4.5 and $5.5)$ is due to greater mobility of $\mathrm{Cd}$ in soil, which enhances plant availability (Gray et al., 1999; Appel \& Ma, 2002). In addition, the presence of chloride formed by the $\mathrm{CdCl}_{2}$ solutions added may have played a role in increasing $\mathrm{Cd}$ uptake. According to McLaughlin et al. (1994), chloride is known for significantly reducing $\mathrm{Cd}$ sorption to soil particles. Cunha et al. (2008) found lower Cd concentration in Z. mays shoots after increasing the soil $\mathrm{pH}$ from 4.9 to 6.0 by liming, and they also verified greater $\mathrm{Cd}$ accumulation in the apoplast of plants grown in limed soil, which was thought to also contribute to diminishing Cd toxicity. Szomolányi \& Lehoczky (2002) verified a decrease in Cd contents in L. sativa leaves in different soils after liming and attributed these decreases to increased adsorption of $\mathrm{Cd}$ to soil particles. Similarly, Melo et al. (2012) observed that liming reduced $\mathrm{Cd}$ concentration in L. sativa in a medium textured Ultisol, but had no effect in a clay-rich Oxisol, demonstrating the importance of clay content as well as soil $\mathrm{pH}$ for regulating $\mathrm{Cd}$ availability to plants. Araújo et al. (2002) found a high correlation between $\mathrm{pH}$ and $\mathrm{Cd}$ adsorption, as well as adsorption of other metals, in Oxisols. The beneficial effects of liming may be due to other factors, notably metal precipitation or complexation and competition with $\mathrm{Ca}^{2+}$ for plant uptake (Tlustos et al., 2006; Bolan \& Duraisamy, 2003).

Table 2 - Comparison of eight plant species for germination and seedling growth in soil contaminated by increasing Cd concentrations at two $\mathrm{pH}$ values ${ }^{\text {a }}$.

\begin{tabular}{lcccc}
\hline \multirow{2}{*}{ Species } & $\begin{array}{c}\mathrm{pH} \\
\left(\mathrm{CaCl}_{2}\right)\end{array}$ & Germination $(\%)$ & Shoots $(\mathrm{mm})$ & Roots $(\mathrm{mm})$ \\
\hline \multirow{2}{*}{ L. sativa } & 4.1 & $52 \pm 7 \mathrm{a}$ & $16.2 \pm 5.9 \mathrm{a}$ & $4.8 \pm 2.3 \mathrm{a}$ \\
\cline { 2 - 5 } & 6.4 & $88 \pm 8 \mathrm{~b}$ & $42.6 \pm 7.5 \mathrm{~b}$ & $16.9 \pm 3.8 \mathrm{~b}$ \\
\hline \multirow{2}{*}{ B. vulgaris } & 4.1 & $63 \pm 19 \mathrm{a}$ & $18.1 \pm 5.2 \mathrm{a}$ & $10.9 \pm 3.0 \mathrm{a}$ \\
\cline { 2 - 5 } & 6.4 & $98 \pm 4 \mathrm{~b}$ & $35.2 \pm 7.9 \mathrm{~b}$ & $22.9 \pm 2.7 \mathrm{~b}$ \\
\hline \multirow{2}{*}{ D. carota } & 4.1 & $33 \pm 10 \mathrm{a}$ & $20.2 \pm 7.6 \mathrm{a}$ & $13.7 \pm 5.5 \mathrm{a}$ \\
\cline { 2 - 5 } & 6.4 & $62 \pm 12 \mathrm{~b}$ & $42.8 \pm 7.5 \mathrm{~b}$ & $27.9 \pm 3.6 \mathrm{~b}$ \\
\hline \multirow{2}{*}{ P. vulgaris } & 4.1 & $79 \pm 9 \mathrm{a}$ & $97.5 \pm 16.6 \mathrm{a}$ & $40.2 \pm 12.6 \mathrm{a}$ \\
\cline { 2 - 5 } & 6.4 & $87 \pm 2 \mathrm{a}$ & $172.2 \pm 54 \mathrm{~b}$ & $82.3 \pm 24 \mathrm{~b}$ \\
\hline \multirow{2}{*}{ A. strigosa } & 4.1 & $53 \pm 19 \mathrm{a}$ & $32.3 \pm 5.2 \mathrm{a}$ & $63.8 \pm 1.6 \mathrm{a}$ \\
\cline { 2 - 5 } & 6.4 & $58 \pm 3 \mathrm{a}$ & $35.2 \pm 2.5 \mathrm{a}$ & $94.6 \pm 7.6 \mathrm{~b}$ \\
\hline \multirow{2}{*}{ O. sativa } & 4.1 & $73 \pm 18 \mathrm{a}$ & $18.0 \pm 8.1 \mathrm{a}$ & $39.4 \pm 1.8 \mathrm{a}$ \\
\cline { 2 - 5 } & 6.4 & $85 \pm 4 \mathrm{a}$ & $37.34 \pm 4.3 \mathrm{~b}$ & $72.7 \pm 8.6 \mathrm{~b}$ \\
\hline \multirow{2}{*}{ Z. mays } & 4.1 & $94 \pm 8 \mathrm{a}$ & $44.0 \pm 3.3 \mathrm{a}$ & $132.8 \pm 6.5 \mathrm{a}$ \\
\hline & 6.4 & $98 \pm 3 \mathrm{a}$ & $70.9 \pm 6.1 \mathrm{~b}$ & $165.2 \pm 8.6 \mathrm{~b}$ \\
\hline & 6.1 & $78 \pm 18 \mathrm{a}$ & $24.9 \pm 3.9 \mathrm{a}$ & $98.2 \pm 4.2 \mathrm{a}$ \\
\hline
\end{tabular}

\footnotetext{
a Percentage of germination are means from treatments: $0,10,40$ and $80 \mathrm{mg} \mathrm{kg}^{-1} \mathrm{Cd}$, germination of all seeds per treatment ( $\left.\mathrm{n}=10\right)$ was considered as $100 \%$. Germination and growth data for treatments with 160 and $320 \mathrm{mg} \mathrm{kg}^{-1} \mathrm{Cd}$ were not included due to high mortality rates. Different letters correspond to significant differences between only two means, related to $\mathrm{pH}$ values (in each species line), by Student's t-test $(p<0.05)$
} 
With respect to the different responses among the studied species, in $L$. sativa and A. strigosa seeds there was a fourfold increase in $\mathrm{LC}_{50}$ values as a result of raising the soil $\mathrm{pH}$, while for Z. mays seeds, there was a twofold increase (Figure 1). At both $\mathrm{pH}$ levels, the species that was most sensitive to $\mathrm{Cd}$ was $D$. carota, and the least sensitive species was $Z$. mays. Overall, the dicotyledonous species were less tolerant to $\mathrm{Cd}$ toxicity than the monocotyledons, indicating that the $\mathrm{LC}_{50}$ is influenced by the genetic characteristics of each species or group and the soil attributes that affect metal availability (Smolders et al., 2009). The effects of metals on the seed germination of different plants also depend on interspecies differences in seed structure, particularly seed coats since they have a wide range of anatomic forms that exist in no other plant organ or tissue (Wierzbicka \& Obidziniska, 1998).

Gong et al. (2001) also observed differences among plants in their response to $\mathrm{Cd}$ phytotoxicity, and that germination and biomass production were less sensitive to $\mathrm{Cd}$ for $P$. vulgaris and A. sativa than for Brassica rapa (turnip) and Lepidium sativum (cress). Cadmium sensitivity can even vary among varieties of the same species, primarily reflecting differences in element transport within the plant, as seen in Oryza sativa (Lai et al., 2009) and Noccaea caerulescens (Whiting et al., 2000).

Seedling growth proved to be a very sensitive endpoint and also proved to be responsive to increases of $\mathrm{Cd}$ in soil, especially in the acidic soil ( $\mathrm{pH} 4.1$ ) (Figure 2 and 3). Shoot and root lengths were negatively affected by $\mathrm{Cd}$ in soil and were directly related to its concentration and availability. $\mathrm{Cd}$ has no known role in higher plants, however, because its uptake is not regulated by physiological limits (plant demand), increasing $\mathrm{Cd}$ concentrations in soil leads to increasing uptake and toxicity (Smolders \& Mertens, 2013) and sometimes following a linear pattern (Guerra et al., 2014).

The dicotyledonous species exhibited differences from the control treatment for the lowest $\mathrm{Cd}$ concentration applied, of $10 \mathrm{mg} \mathrm{kg}^{-1}$ (L. sativa and B. vulgaris), and for the next concentration, $40 \mathrm{mg} \mathrm{kg}^{-1}$ (D. carota and P. vulgaris), in the

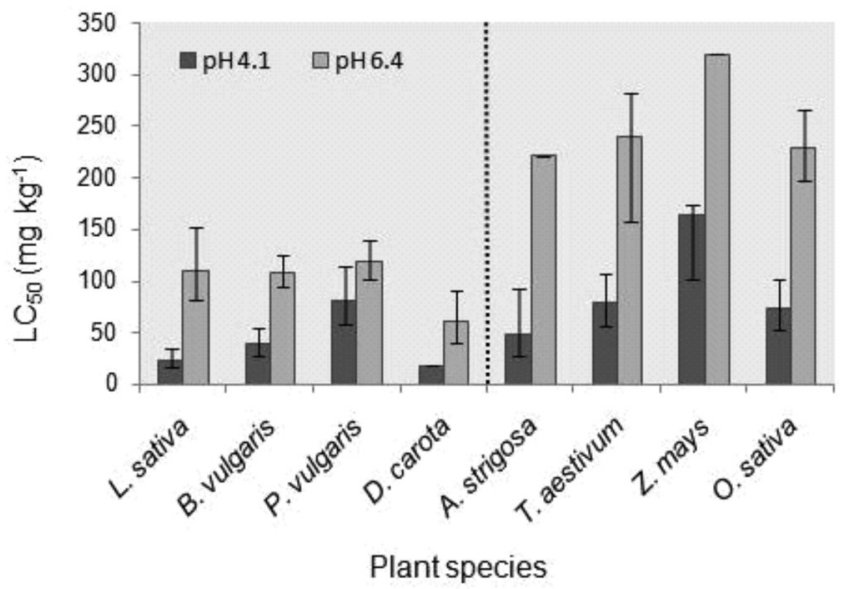

Figure $1-\mathrm{Cd}$ concentration in soil causing $50 \%$ inhibition of germination in eight different plant species at two $\mathrm{pH}$ levels. Values represent the mean \pm standard deviation $(\mathrm{n}=3)$. Dicotyledons are on the left side of the dotted line and monocotyledons on the right side. soil with $\mathrm{pH}$ of 4.1 (Figure 2). Above the concentration of

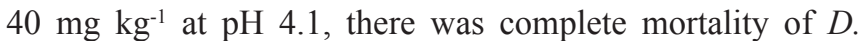
carota. The higher $\mathrm{pH}$ level led to greater shoot growth for these species (Figure 2), most likely as a result of reduced $\mathrm{Cd}$ availability or an increase in the concentration of $\mathrm{Ca}^{2+}$ caused by liming, which enhances plant tolerance because $\mathrm{Cd}$ and $\mathrm{Ca}$ compete for the same adsorption sites in roots (Guo et al., 2011). Thus, raising soil $\mathrm{pH}$ by liming, along with another treatment such as the addition of nanoparticles $\left(\mathrm{Fe}_{3} \mathrm{O}_{4}\right.$ or $\alpha-\mathrm{Fe}_{2} \mathrm{O}_{3}$ ) or biochar, might be useful techniques in alleviating Cd phytoxicity in soils (Bian et al., 2014; Wang et al., 2012).

Higher tolerance of monocotyledons at the higher soil pH level was confirmed (Figure 3). However, a comparison of the growth of dicotyledons and monocotyledons showed that the latter group was less sensitive to the increases in $\mathrm{Cd}$ concentrations in the soil. A study by Baderna et al. (2015) also suggested higher sensitivity in dicotyledonous species (cucumber and cress) to toxic elements such as chromium and mercury than a monocotyledon (sorghum), nevertheless, none of these species presented $\mathrm{Cd}$ toxicity at the range of concentrations used: $0-10 \mathrm{mg} \mathrm{kg}^{-1}$ (NOEC).
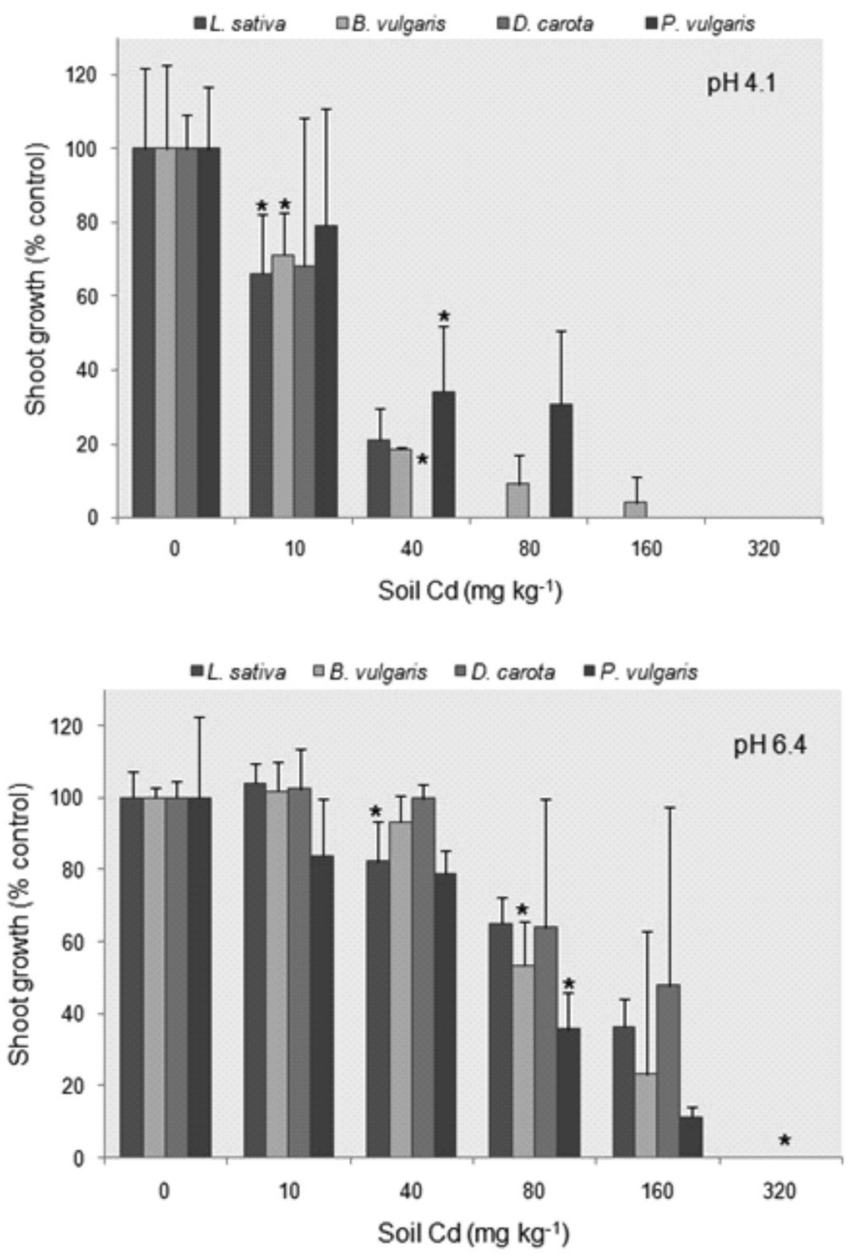

Figure 2 - Shoot growth (length) of four dicotyledenous species, presented as a percentage of the mean of the control (no Cd), for soil at $\mathrm{pH} 4.1$ or 6.4. Bars represent the standard deviation of the mean $(n=3)$. * indicates the first concentration to differ from control treatment (LOEC), by Dunnett's test $(p<0.05)$. 
Cadmium is known to affect the activity of the photosynthetic enzyme Rubisco (Ribulose 1,5 bisphosphate carboxylase/oxygenase), causing adverse effects, as seen in lettuce (Dias et al., 2013). However, Z. mays (Figure 3) possesses a $\mathrm{C}_{4}$ photosynthetic system, which allows greater biomass production and more rapid development because of the enzyme phosphoenolpyruvate carboxylase (PEPC), which is also known to attenuate oxidative stress caused by toxic metals such as Cd (Srivastava et al., 2012), and such characteristics may contribute to the higher tolerance of this species. It is possible that the higher tolerance to $\mathrm{Cd}$ shown by the other monocotyledon species studied is related to the presence of the PEPC enzyme in these species: even though they have a $\mathrm{C}_{3}$ cycle, they possess PEPC with structures very similar to those found in Z. mays. Such explanation is based on information described by Matsuoka \& Hata (1987) that identified, by peptide mapping, similarities among PEPC subunits of $O$. sativa, $T$. aestivum and $Z$. mays.

The calculated LOEC and NOEC index values for all eight species studied are shown in Table 3. Regardless of the species, both parameters were higher at $\mathrm{pH} 6.4$ than at $\mathrm{pH} 4.1$, reflecting decreased $\mathrm{Cd}$ availability and other effects of liming
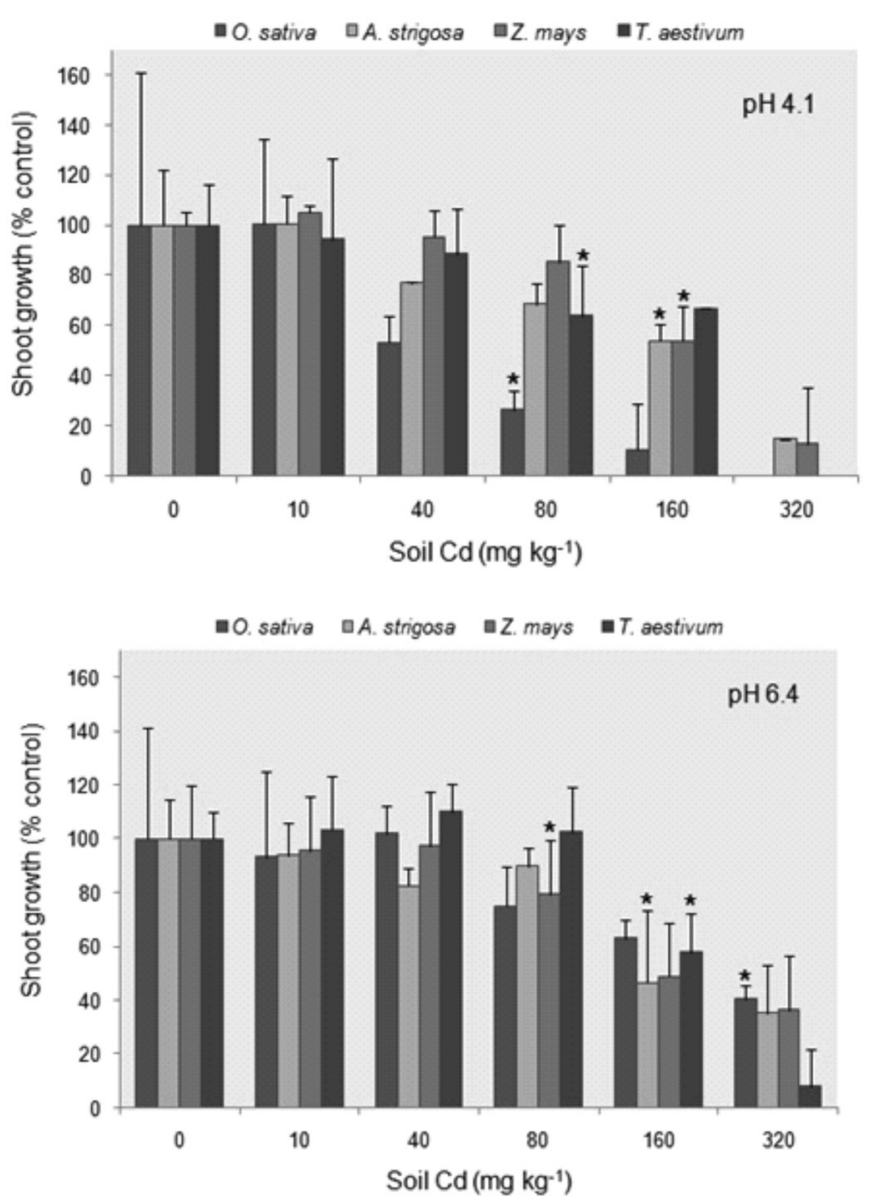

Figure 3 - Shoot growth (length) of four monocotyledenous species, presented as a percentage of the mean of the control (no Cd), for soil at $\mathrm{pH}$ 4.1 or 6.4. Bars represent the standard deviation of the mean $(n=3)$. Asterisk indicates the first concentration to differ from control treatment (LOEC), by Dunnett's test $(p<0.05)$. discussed previously.

For all species except $D$. carota, germination had higher LOEC values than shoot or root growth, suggesting lower sensitivity to $\mathrm{Cd}$ toxicity, which means that only assessing germination may underestimate $\mathrm{Cd}$ toxicity (Figure 4). Zayneb et al. (2015) also observed similar effects in fenugreek (Trigonella foenum-graecum), in which germination was a less sensitive endpoint compared to seedling growth. Studies have shown that seed coats are effective barriers to metals and can prevent contamination of embryos until the seed coat is torn apart by the germinating embryonic root (Munzuroglu $\&$ Geckil, 2002). This protective effect would enhance $\mathrm{Cd}$ tolerance and also explain the differences among species that vary in seed size, coat, endosperm etc. For instance, in a study with different Vicia faba cultivars, Rahoui et al. (2008) found that a longer delay in germination due to $\mathrm{Cd}$ toxicity was correlated with the decrease in the availability of amino acids and sugars in the reserve tissues.

The sensitivity of seedlings to Cd toxicity is likely related to their vulnerability to water stress, since $\mathrm{Cd}$ is known to affect the permeability of cellular membranes (Benavides et al., 2005; Nagajyoti et al., 2010). This effect is consistent with a study by An (2004), which showed germination of $Z$. mays, Cucumis sativus, T. aestivum and Sorghum bicolor to be a less responsive endpoint for assessing Cd toxicity in soil, as compared to shoot and root growth. Similar findings have been reported for other species (Gong et al., 2001; Luan et al., 2008).

Table 3 - Lowest Observed Effect Concentration (LOEC) and No Observe Effect Concentration (NOEC) indexes for $\mathrm{Cd}$ in eight plant species grown in soil at two different values ${ }^{\text {a }}$.

\begin{tabular}{lccccccc}
\hline & & \multicolumn{7}{c}{ Soil pH } \\
\cline { 3 - 8 } Species & Index & 4.1 & 6.4 & 4.1 & 6.4 & 4.1 & 6.4 \\
\cline { 3 - 8 } & & \multicolumn{2}{c}{ Germination } & \multicolumn{2}{c}{ Shoots } & \multicolumn{2}{c}{ Roots } \\
\hline \multirow{2}{*}{ L. sativa } & LOEC & 40 & 160 & 10 & 40 & 10 & 80 \\
& NOEC & 10 & 80 & 0 & 10 & 0 & 40 \\
\hline B. & LOEC & 40 & 160 & 10 & 80 & 40 & 160 \\
vulgaris & NOEC & 10 & 80 & 0 & 40 & 10 & 80 \\
\hline \multirow{2}{*}{ D. carota } & LOEC & 40 & 80 & 40 & 320 & 40 & 160 \\
& NOEC & 10 & 40 & 10 & 160 & 10 & 80 \\
\hline P. & LOEC & 160 & 160 & 40 & 80 & 40 & 80 \\
vulgaris & NOEC & 80 & 80 & 10 & 40 & 10 & 40 \\
\hline A. & LOEC & 40 & n.s. & 160 & 160 & 160 & 160 \\
Strigosa & NOEC & 10 & n.s. & 80 & 80 & 80 & 80 \\
\hline \multirow{2}{*}{ O. sativa a } & LOEC & 80 & 320 & 80 & 320 & 80 & 320 \\
& NOEC & 40 & 160 & 40 & 160 & 40 & 160 \\
\hline \multirow{2}{*}{ Z. mays } & LOEC & 160 & 320 & 160 & 80 & 80 & 160 \\
\hline T. & NOEC & 80 & 160 & 80 & 40 & 40 & 80 \\
\hline aestivum & LOEC & 80 & 320 & 80 & 160 & 80 & 160 \\
\hline
\end{tabular}

${ }^{a}$ Indexes determined by Dunnett's test $(p<0.05)$ between each Cd treatment and the control. n.s.: no differences from control, indexes not determined. 


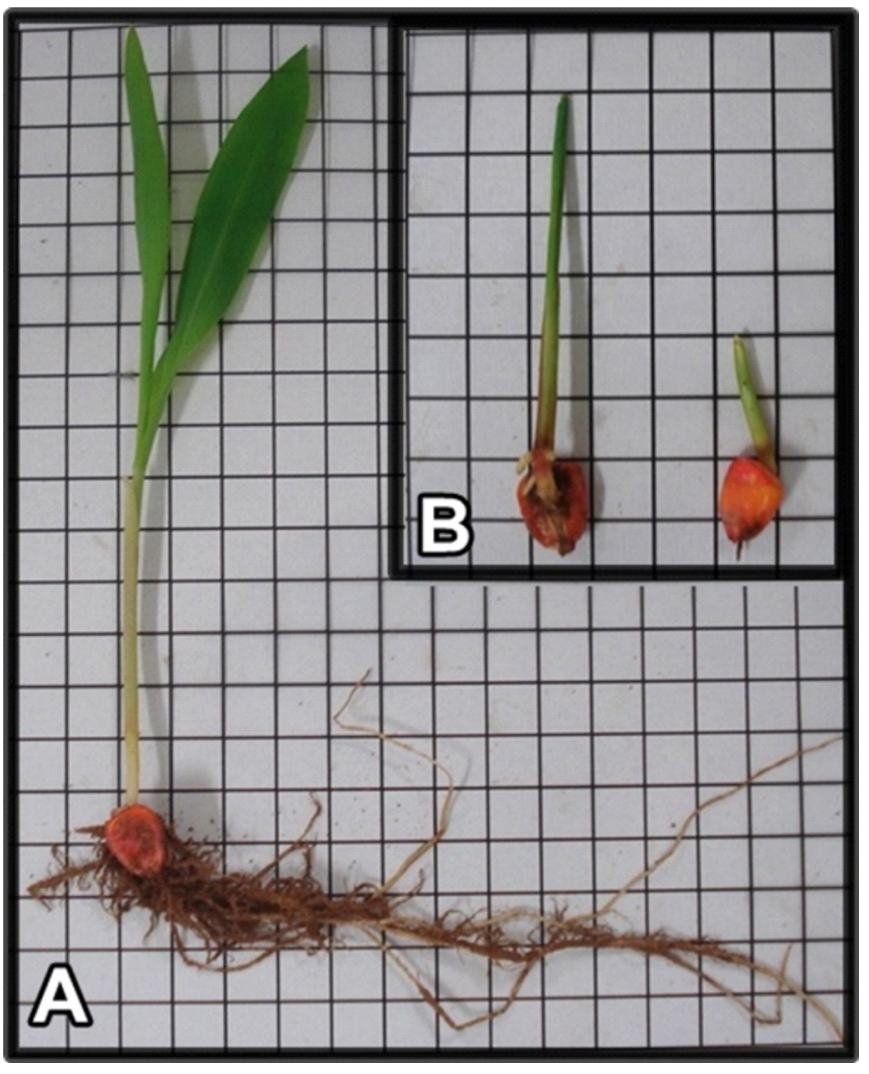

Figure 4 - Zea mays seedlings grown in Cd-contaminated soil for 10 days (A: $10 \mathrm{mg} \mathrm{kg}^{-1}$ and B: $40 \mathrm{mg} \mathrm{kg}^{-1}$ ), soil $\mathrm{pH}$ of 6.4. Scale: each side of the square represents $1 \mathrm{~cm}$.

Toxicities tend to be more pronounced for seedling roots than shoots, owing to more immediate contact with the soil source of toxicity (An, 2004). However, for L. sativa, $B$. vulgaris, and $Z$. mays, there were higher LOEC values for roots than for shoots, which means that roots were less affected by $\mathrm{Cd}$, possibly because of higher translocation of this metal to the shoots during initial development or simply because the root tissue is indeed more tolerant. In a study by Whiting et al. (2000) with two varieties of $N$. caerulescens grown in Cd-contaminated soil, dry matter production or root length did not differ significantly despite a 25 -fold difference in the $\mathrm{Cd}$ contents of the shoots. Such findings suggest that both immobilization and translocation can promote $\mathrm{Cd}$ tolerance in roots, and emphasize the importance of genotypic variations in $\mathrm{Cd}$ uptake, transport, and accumulation in shoots for explaining species and varietal differences in $\mathrm{Cd}$ tolerance (Hall, 2002).

\section{CONCLUSION}

Seedling growth of shoots and roots is a responsive endpoint for $\mathrm{Cd}$ ecotoxicological risk assessments with O. sativa, A. strigosa, T. aestivum, Z. mays, L. sativa, B. vulgaris, D. carota, and $P$. vulgaris. These assessments should be carried out using dicotyledenous species (e. g. $L$. sativa and $B$. vulgaris) at soil with $\mathrm{Cd}$ concentrations lower than $80 \mathrm{mg} \mathrm{kg}^{-1}$, whereas monocotyledons, which generally presented higher tolerance to $\mathrm{Cd}$, are more appropriate for higher concentrations. Increasing the $\mathrm{pH}$ by liming can be an effective method to alleviate $\mathrm{Cd}$ toxicity.

\section{ACKNOWLEDGMENTS}

The authors thank the São Paulo Research Foundation (FAPESP) for granting a master's degree scholarship to the first author and also for the financial support of the project (2011/14744-6 and 2012/05490-3).

\section{REFERENCES}

ABREU, C.A., ABREU, M.F., SOARES, L. H. \& ANDRADE, J.C. 1997. The effects of the DTPA extraction conditions on the determination of micronutrients in Brazilian soils. Commun. Soil Sci. Plant Anal. 28(1-2): 1-11. http://dx.doi. org/10.1080/00103629709369767

ALLOWAY, B.J. 2013. Heavy Metals in Soils: trace metals and metalloids in soils and their bioavailability. 3rd edn, Springer, Dordrecht, Netherlands, 613p. http://dx.doi.org/10.1007/978-94007-4470-7

AN, Y.J. 2004. Soil ecotoxicity assessment using cadmium sensitive plants. Environ. Pollut. 127(1): 21-26. http://dx.doi.org/10.1016/ S0269-7491(03)00263-X

AN, Y.J., KIM, Y.M., KWON, T.I., \& JEONG, S.W. 2004. Combined effect of copper, cadmium and lead upon Cucumis sativus growth and bioaccumulation. Sci. Total Environ. 326(13): 85-93. http://dx.doi.org/10.1016/j.scitotenv.2004.01.002

APPEL, C. \& MA, L. 2002. Concentration, pH, and surface charge effects on cadmium and lead sorption in three tropical soils. J. Environ. Qual. 31(2): 581-589. http://dx.doi.org/10.2134/ jeq2002.0581

ARAÚJO, G.C.L., GONZALEZ, M.H., FERREIRA, A.G., NOGUEIRA, A.R.A. \& NÓBREGA, J.A. 2002. Effect of acid concentration on closed-vessel microwave-assisted digestion of plant materials. Spectrochim. Acta B 57(12): 2121-2132. http:// dx.doi.org/10.1016/S0584-8547(02)00164-7

ATSDR (Agency for Toxic Substances and Disease Registry). 2015. CERCLA Priority List of Hazardous Substances. Available at: http://www.atsdr.cdc.gov/SPL/ [Accessed Aug, 2016]

ATSDR (Agency for Toxic Substances and Disease Registry). 2008. Toxicological Profile for Cadmium: Draft for Public Comment. U.S. Department of Health and Human Services, Atlanta, U.S.

BADERNA, D., LOMAZZI, E., POGLIAGHI, A., CIACCIA, G., LODI, M. \& BENFENATI, E. 2015. Acute toxicity of seven metals alone and in mixture: are Italian soil threshold concentrations suitable for plant protection? Environ. Res. 140: 102-111. http://dx.doi.org/10.1016/j.envres.2015.03.023

BENAVIDES, M.P., GALLEGO, S.M. \& TOMARO, M.L. 2005. Cadmium toxicity in plants. Braz. J. Plant Physiol. 17(1): 21-34. http://dx.doi.org/10.1590/S1677-04202005000100003

BIAN, R., JOSEPH, S., CUI, L., PAN, G., LI, L., LIU, X., ZHANG, A., RUTlidge, H., WONG, S., CHIA, C., MARJO, C., GONG, B., MUNROE, P. \& DONNE, S. 2014. A three-year experiment confirms continuous immobilization of cadmium and lead in contaminated paddy field with biochar amendment. J. Hazard. Mater. 272: 121-128. http://dx.doi.org/10.1016/j. jhazmat.2014.03.017

BOLAN, N. S. \& DURAISAMY, V. 2003. Role of inorganic and organic soil amendments on immobilisation and phytoavailability of heavy metals: a review involving specific case studies. Soil 
Res. 41(3): 533-555. http://dx.doi.org/10.1071/SR02122

BOLUDA, R., ROCA-PÉREZ, L. \& MARIMÓN, L. 2011. Soil plate bioassay: An effective method to determine ecotoxicological risks. Chemosphere 84(1): 1-8. http://dx.doi.org/10.1016/j. chemosphere.2011.02.013

CAMARGO, O.A., MONIZ, A.C., JORGE, J.A. \& VALADARES, J.M.A.S. 2009. Methods for chemical and physical analysis of soils from the Agronomic Institute (technical report, 106). IAC, Campinas, SP. Brazil. Available at: www.iac.sp.gov.br/ publicacoes/porassunto/pdf/boletim106.pdf. [Accessed Oct 10, 2015] (in Portuguese).

CUNHA, K.P.V., NASCIMENTO, C.W.A., PIMENTEL, R.M.M. \& FERREIRA, C.P. 2008. Cellular localization of cadmium and structural changes in maize plants grown on a cadmium contaminated soil with and without liming. J. Hazard. Mater. 160(1): 228-234. http://dx.doi.org/10.1016/j. jhazmat.2008.02.118

DIAS, M.C., MONTEIRO, C., MOUTINHO-PEREIRA, J., CORREIA, C., GONÇALVES, B. \& SANTOS, C. 2013. Cadmium toxicity affects photosynthesis and plant growth at different levels. Acta Physiol. Plant. 35(4): 1281-1289. http:// dx.doi.org/10.1007/s11738-012-1167-8

FRATTINI, C.T.A. \& KALCKMANN, R.E. 1967. Correlation among a few methods for Carbon determination. Pesq. Agropec. Bras. 2: 259-261. (in Portuguese).

GORSUCH, J.W., LOWER, W.R., LEWIS, M.A. \& WANG, W. 1991. Plants for Toxicity Assessment: Second Volume, ASTM STP 1115, Philadelphia, USA.

GONG, P., WILKE, B.M., STROZZI, E. \& FLEISCHMANN, S. 2001. Evaluation and refinement of a continuous seed germination and early seedling growth test for the use in the ecotoxicological assessment of soils. Chemosphere 44(3): 491-500. http://dx.doi. org/10.1016/S0045-6535(00)00280-0

GRAY, C.W., MCLAREN, R.G., ROBERTS, A.H.C. \& CONDRON, L.M. 1999. Effect of soil $\mathrm{pH}$ on cadmium phytoavailability in some New Zealand soils. New Zeal. J. Crop Hort. 27: 169-179. http://dx.doi.org/10.1080/01140671.1999.9514093

GUERRA, F., TREVIZAM, A.R., FIOR, R.C. \& MURAOKA, T. 2014. Cadmium phytoavailability in soils and evaluation of extractant effectiveness using an isotope technique. Sci. Agr. 71(5): 345-355. http://dx.doi.org/10.1590/0103-9016-2013-0305

GUO, W., HU, S., XIAO, Y., ZHANG, H. \& XIE, X. 2010. Direct determination of trace cadmium in environmental samples by dynamic reaction cell inductively coupled plasma mass spectrometry. Chemosphere 81(11): 1463-1468. http://dx.doi. org/10.1016/j.chemosphere.2010.08.056

GUO, X.F., WEI, Z.B., WU, Q.T., QIU, J.R. \& ZHOU, J.L. 2011. Cadmium and zinc accumulation in maize grain as affected by cultivars and chemical fixation amendments. Pedosphere 21(5): 650-656. http://dx.doi.org/10.1016/S1002-0160(11)60167-7

HALL, J.L. 2002. Cellular mechanisms for heavy metal detoxification and tolerance. J. Exp. Bot. 53(366): 1-11. http:// dx.doi.org/10.1093/jexbot/53.366.1

HAMILTON, M.A., RUSSO, R.C. \& THURSTON, R.V. 1977. Trimmed Spearman-Karber method for estimating median lethal concentrations in toxicity bioassays. Environ. Sci. Technol. 11(7): 714-719. http://dx.doi.org/10.1021/es60130a004

LAI, H.Y., SU, S.W., GUO, H.Y. \& CHEN, Z.S. 2009. Phytoremediation and the uptake characteristics of different rice varieties growing in Cd- or As-contaminated soils in Taiwan. In: Technical bulletin - Food \& Fertilizer Technology Center 182: 1-13, Taipei City, Taiwan.

LEI, M., ZHANG, Y., KHAN, S., QIN, P. \& LIAO, B. 2010. Pollution, fractionation, and mobility of $\mathrm{Pb}, \mathrm{Cd}, \mathrm{Cu}$, and $\mathrm{Zn}$ in garden and paddy soils from a $\mathrm{Pb} / \mathrm{Zn}$ mining area. Environ. Monit. Assess. 168(1-4): 215-222. http://dx.doi.org/10.1007/ s10661-009-1105-4

LOUREIRO, S., SANTOS, C., PINTO, G., COSTA, A., MONTEIRO, M., NOGUEIRA, A.J.A. \& SOARES, A.M.V.M. 2006. Toxicity assessment of two soils from Jales Mine (Portugal) using plants: growth and biochemical parameters. Arch. Environ. Con. Tox. 50(2): 182-190. http://dx.doi.org/10.1007/s00244-004-0261-3

LUAN, Z.Q., CAO, H.C. \& YAN, B.X. 2008. Individual and combined phytotoxic effects of cadmium, lead and arsenic on soybean in Phaeozem. Plant Soil Environ. 54(9): 403-411.

MATSUOKA, M. \& HATA, S. 1987. Comparative studies of phosphoenolpyruvate carboxylase from $\mathrm{C} 3$ and $\mathrm{C} 4$ plants. Plant Physiol. 85(4): 947-951. http://www.jstor.org/stable/4271028

MCLAUGHLIN, M.J., PALMER, L., TILLER, K., BEECH, T.A. \& SMART, M. 1994. Increased soil salinity causes elevated cadmium concentrations in field-grown potato tubers. J. Environ. Qual. 23(5): 1013-1018. http://dx.doi.org/10.2134/ jeq1994.00472425002300050023x

MELO, L.C.A., ALLEONI, L.R.F., SWARTJES, F.A. \& DA SILVA, E.B. 2012. Cadmium uptake by lettuce (L. sativa) as basis for derivation of risk limits in soils. Hum. Ecol. Risk Assess. 18(4): 888-901. http://dx.doi.org/10.1080/10807039.2012.688716

MUNZUROGLU, O. \& GECKIL, H. 2002. Effects of metals on seed germination, root elongation, and coleoptile and hypocotyl growth in Triticum aestivum and Cucumis sativus. Arch. Environ. Con. Tox. 43(2): 203-213. http://dx.doi.org/10.1007/ s00244-002-1116-4

NAGAJYOTI, P.C., LEE, K.D. \& SREEKANTH, T.V.M. 2010. Heavy metals, occurrence and toxicity for plants: a review. Environ. Chem. Lett. 8(3): 199-216. http://dx.doi.org/10.1007/ s10311-010-0297-8

OECD (Organisation for Economic Co-operation and Development). 2006. OECD guidelines for the testing of chemicals. Terrestrial Plant Test: Seedling Emergence and Seedling Growth Test, Paris.

PEREIRA, R., MARQUES, C.R., SILVA FERREIRA, M.J., NEVES, M.F.J.V., ANTUNES, S.C.C., MENDO, S. \& GONÇALVES, F. 2009. Phytotoxicity and genotoxicity of soils from an abandoned uranium mine area. Appl. Soil Ecol. 42(3): 209-220. http:// dx.doi.org/10.1016/j.apsoil.2009.04.002

RAHOUI, S., CHAOUI, A. \& EL FERJANI, E. 2008. Differential sensitivity to cadmium in germinating seeds of three cultivars of faba bean (Vicia faba L.). Acta Physiol. Plant. 30(4): 451-456. http://dx.doi.org/10.1007/s11738-008-0142-x

RAIJ, B., ANDRADE, J.C., CANTARELLA, H. \& QUAGGIO, J.A. 2001. Chemical analysis for the assessment of fertility in tropical soils. Campinas: Instituto Agronômico, Campinas, Sao Paulo, 285p. (in Portuguese).

SELIM, H.M. \& ISKANDAR, A. 1999. Fate and transport of heavy metals in the vadose zone. Lewis Publishers, Boca Raton, Florida, 344p.

SMOLDERS, E. \& MERTENS, J. 2013. Cadmium. In: Alloway, B.J., ed. Heavy metals in soils: Trace metals and metalloids in soils and their bioavailability, UK: Springer, Dordrecht, pp. 283311.

SMOLDERS, E., OORTS, K., VAN SPRANG, P., SCHOETERS, I., JANSSES, C.R., MCGRATH, S.P. \& MCLAUGHLIN, M.J. 2009. Toxicity of trace metals in soil as affected by soil type and aging after contamination: using calibrated bioavailability models to set ecological soil standards. Environ. Toxicol. Chem. 28(8): 1633-1642. http://dx.doi.org/10.1897/08-592.1

SRIVASTAVA, J., CHANDRA, H., NAUTIYA, A.R.L \& KALRA, J.S. 2012. Response of C3 and C4 plant systems exposed to heavy metals for phytoextraction at elevated atmospheric $\mathrm{CO}_{2}$ and at 
elevated temperature. In: Srivastava, J.K., ed. Environmental Contamination, InTech, Rijeka, Croatia, pp. 3-16.

SZOMOLÁNYI, A. \& LEHOCZKY, E. 2002. Study on the Cd uptake by lettuce plants in liming experiment. Acta Biol. Szeged. 46(3-4): 123-124.

TLUSTOŠ, P., SZÁKOVÁ, J., KOŘÍNEK, K., PAVLÍKOVÁ, D., HANČ, A \& BALÍK, J. 2006. The effect of liming on cadmium, lead, and zinc uptake reduction by spring wheat grown in contaminated soil. Plant Soil Environ. 52(1): 16-24. http://www. agriculturejournals.cz/publicFiles/50512.pdf

USEPA (Environmental Protection Agency). 1996. Ecological Effects Test Guidelines, OPPTS 850.4200, Seed Germination/ Root Elongation Toxicity Test. EPA 712-C-96-154, Public Draft, Washington, DC.

USEPA (Environmental Protection Agency). 1999. Trimmed Spearman-Karber estimation of $\mathrm{LC}_{50}$ values users' manual, U. S. EPA, Office of Research and Development, National Exposure Research Laboratory-Ecosystems Research Division, Center for Exposure Assessment Modeling (CEAM), Athens, Georgia.

WALKER, C.H., HOPKIN, S.P., SIBLY, R.M. \& PEAKALL, D.B. 2001. Principles of Ecotoxicology, T\&F STM, London, 386p.

WALKLEY, A. \& BLACK, I.A. 1934. An examination of Degtjareff Method for determining soil organic matter and a proposed modification of the chromic acid titration method. Soil Sci. 37(1): 29-37.

WANG, M., CHEN, L., CHEN, S. \& MA, Y. 2012. Alleviation of cadmium-induced root growth inhibition in crop seedlings by nanoparticles. Ecotox. Environ. Safe. 79: 48-54. http://dx.doi. org/10.1016/j.ecoenv.2011.11.044

WIERZBICKA, M. \& OBIDZINSKA, J. 1998. The effect of lead on seed inhibitions and germination in different plant species. Plant Sci. 137(2): 155-171. http://dx.doi.org/10.1016/S01689452(98)00138-1

WHITING, S.N., LEAKE, J.R., MCGRATH, S.P. \& BAKER, A.J.M. 2000. Positive responses to $\mathrm{Zn}$ and $\mathrm{Cd}$ by roots of the $\mathrm{Zn}$ and $\mathrm{Cd}$ hyperaccumulator Thlaspi caerulescens. New Phytol. 145(2): 199-210. http://dx.doi.org/10.1046/j.1469-8137.2000.00570.x

ZAYNEB, C., BASSEM, K., ZEINEB, K., GRUBB, C. D., NOUREDDINE, D., HAFEDH, M. \& AMINE, E. 2015. Physiological responses of fenugreek seedlings and plants treated with cadmium. Environ. Sci. Pollut. R. 22(14): 1067910689. http://dx.doi.org/10.1007/s11356-015-4270-8

ZHOU, J.M., DANG, Z., CAI, M.F. \& LIU, C.Q. 2007. Soil heavy metal polution around the Dabaoshan Mine, Guangdong Province, China. Pedosphere 17(5): 588-594. http://dx.doi. org/10.1016/S1002-0160(07)60069-1 